J. W. Wamboka provided valuable technical help. The chloroquine phosphate and placebo tablets were kindly provided by May and Baker Ltd. This study was supported in part by Contract No. PH 43-67-47 and PH 43-67-1343 from the National Cancer Institute, Bethesda, Md., and by funds from Makerere University College $(438 / 69)$.

\section{References}

Bruce-Chwatt, L. J. (1956). Bulletin of the World Health Organization, $15,513$.

Gebbie, D. A. M., et al. (1964). Lancet, 2, 392.

Hamilton, P. J. S., Gebbie, D. A. M., Hutt, M. S. R., Lothe, F., and Wilks, N. E. (1966). British Medical fournal, 2, 548

Hamilton, P. J. S., et al. (1965). East African Medical fournal, 42, 191.

Hamilton, P. J. S., et al. (1967). British Medical fournal, 3, 823.
Hamilton, P. J. S., et al. (1969). Lancet, 2, 209.

Hutt, M. S. R. and Fluck, C. (1970). Unpublished observations. Lowenthal, M. N., and Hutt, M. S. R. (1968). East African Medical fournal, $45,100$.

Marsden, P. D., et al. (1965). British Medical fournal, 1, 89.

Marsden, P. D., et al. (1967). Bulletin of the World Health Organization, (a)

36, 901 .

Marsden, P. D., and Hamilton, P. J. S. (1969). British Medical fournal, 1, 99 Paliwoda, T., and Hutt, M. S. R. (1968). East African Medical fournal, 45, 1 .

Pitney, W. R. (1968). Transactions of the Royal Society of Tropical Medicine and Hygiene, 62, 717.

Sagoe, A. (1970). British Medical fournal, 3, 378.

Watson-Williams, E. J., and Allan, N. C.' (1968). British Medical fournal, 4, 793.

Wells, J. V. (1968). Clinical and Experimental Immunology, 3, 943.

Wood, J. B., et al. (1970). East African Medical fournal, 47, 191.

Ziegler, J. L., Cohen, M. H., and Hutt, M. S. R. (1969). British Medical fournal, 4, 15.

\title{
Tropical Splenomegaly Syndrome in Zambia: Further Observations and Effects of Cycloguanil and Proguanil
}

\author{
M. N. LOWENTHAL, E. C. O'RIORDAN, M. S. R. HUTT
}

British Medical fournal, 1971, 1, 429-432

\section{Summary}

Nineteen Zambian patients with the tropical splenomegaly syndrome and sinusoidal lymphocytosis on liver biopsy were studied. The association of macrobulinaemia with the tropical splenomegaly syndrome has again been confirmed. Sixteen patients were treated with antimalarials-12 with cycloguanil pamoate alone, 3 with cycloguanil and proguanil, and 1 with proguanil alone. Twelve patients were observed for periods of sufficient length for the drug effect to be assessed, and in 11 there was a good response in terms of decrease in spleen size.

Cycloguanil pamoate may be of value both for prophylaxis and treatment in areas where tropical splenomegaly syndrome is endemic.

\section{Introduction}

The tropical splenomegaly syndrome has been the subject of several reviews during the past two years (Pitney, 1968; British Medical fournal, 1967, 1969). Previous studies in Zambia showed that tropical splenomegaly syndrome occurring there was similar to that described in other parts of Africa (Lowenthal et al., 1966) and also that long-term antimalarial prophylaxis with proguanil was beneficial (Lowenthal and Hutt, 1968). Similar results, with more complete remissions, have been found in two larger series of cases treated with proguanil in Nigeria (Watson-Williams and Allan, 1968; Sagoe, 1970). A double-blind trial on cases of tropical splenomegaly syndrome in Uganda with long-term chloroquine therapy has also shown significant improvement in patients' symptoms and spleen size (Stuiver et al., 1971). Earlier experience with long-term treatment with proguanil

\section{Central Fospital. Ndola, Zambia}

M. N. LOWENTHAL, M.B., M.R.C.P.ED., Physician Specialist

E. C. O'RIORDAN, M.B., B.SC.(PATH.), Specialist Pathologist

\section{St. Thomao's Hoopital Medical School, London S.E.1}

M. S. R. HUTT, M.D., F.R.C.P., F.R.C.PATH., Professor of Geographical Pathology showed that it was not always easy to ensure that the drug was continually taken over a long period of time. For this reason it was decided to treat cases of tropical splenomegaly syndrome with the depot injectable antimalarial cycloguanil pamoate (Camolar) either alone or in some cases combined with proguanil.

\section{Patients and Methods}

Nineteen patients (13 male and 6 female) who fulfilled the diagnostic criteria for tropical splenomegaly syndrome (Marsden and Hamilton, 1969) were admitted to the wards of the Ndola Central Hospital during the period December 1968 to March 1970. In all cases a detailed clinical history and physical examination were carried out. Spleen size was measured along the longest palpable axis of the organ. All clinical examinations were made by one of us (M.N.L.). Laboratory examinations included: haemoglobin, white count and differential, thick blood film for malarial parasites, urine analysis and stool examination for parasites in all cases, haemoglobin electrophoresis in 14 patients, and sternal marrow puncture in 12 patients. Percutaneous liver biopsy was performed in all 19 patients and the diagnosis of tropical splenomegaly syndrome with hepatic sinusoidal lymphocytosis was established according to previous criteria (Marsden et al., 1967). Repeat liver biopsies were done in five patients at intervals after treatment had started. Other investigations, including plasma protein levels, empirical liver function tests, agglutinations against brucella and salmonella organisms, serum iron levels, and chest $x$-ray examination, were done in most cases.

Immunological Studies.-IgM levels were measured in 17 cases by a modification of the method of Mancini et al. (1965). The assay was repeated in seven cases after therapy, and in three of these a third estimation was made after a further interval. For the purpose of providing control values IgM was assayed in two other groups of patients. The first included patients with moderate to massive splenomegaly due to chronic myeloid leukaemia ( 3 cases), primary myeloid metaplasia (2), schistosomiasis (5), tropical splenomegaly syndrome without hepatic sinusoidal lymphocytosis (4), hepatic cirrhosis (6), and one case each of tuberculosis, amyloidosis, and con- 
genital hepatic fibrosis; the second group comprised seven patients without splenomegaly who were admitted with trauma or eye diseases.

\section{Treatment}

Antimalarial.-Thirteen patients were given a short initial course of chloroquine of up to $1.5 \mathrm{~g}$ total over two to three days. Previous experience in Zambia and Uganda had shown that this would not affect spleen size. In the assessment of long-term antimalarial therapy 12 patients were given cycloguanil only, three received both cycloguanil and proguanil, and one case was given proguanil only. Details of the proguanil and cycloguanil regimens are shown in Tables II and III. Three patients (Cases 15, 17, and 18) were not treated with either drug and are briefly included in this paper in regard to their clinical and immunological findings. Cases
5,6 , and 14 received large doses of cycloguanil at a single administration, $3 \mathrm{ml}$ into each buttock. No complications attended the use of cycloguanil in this series or the employment of these unusually large doses of proguanil.

Other Therapy.-The complex clinical situation in many of these patients required the administration of a variety of other drugs. One patient (Case 1) was eventually given a short course of chlorambucil (28 $\mathrm{mg}$ total) and prednisolone (140 mg total). She was also given oral iron, folic acid, and vitamin $B_{12}$. Two patients (Cases 2 and 6 ) received iron-dextran by total dose infusion. None of the other drugs used are likely to have affected the size of the spleen or the blood piciure.

\section{Results}

The initial clinical and laboratory findings are given in Table I and are essentially similar to those previously reported. The

TABLE I-Clinical and Laboratory Data on 19 Patients with Tropical Splenomegaly Syndrome

\begin{tabular}{|c|c|c|c|c|c|c|c|c|c|c|}
\hline \multirow{2}{*}{$\begin{array}{l}\text { Case } \\
\text { No. }\end{array}$} & \multirow{2}{*}{ Age } & \multirow{2}{*}{ Sex } & \multirow{2}{*}{$\underset{(\mathrm{cm})}{\text { Spleen }}+$} & \multirow{2}{*}{$\operatorname{IgM}$} & \multirow{2}{*}{$\begin{array}{c}\mathrm{Hb} \\
\text { Electr. }\end{array}$} & \multicolumn{3}{|c|}{ Liver Biopsy } & \multirow{2}{*}{$\begin{array}{l}\text { Liver } \\
(\mathrm{cm})\end{array}$} & \multirow{2}{*}{ Comments } \\
\hline & & & & & & H.S.L. & $\begin{array}{c}\text { Portal } \\
\text { Lymphocytes }\end{array}$ & $\begin{array}{l}\text { Portal } \\
\text { Fibrosis }\end{array}$ & & \\
\hline $\begin{array}{r}1 \\
2 \\
3 \\
4 \\
5 \\
6 \\
7 \\
8 \\
9 \\
10 \\
11 \\
12 \\
13 \\
14 \\
15 \\
16 \\
17 \\
18 \\
19\end{array}$ & $\begin{array}{r}45 \\
16 \\
* 50 \\
57 \\
* 60 \\
* 50 \\
29 \\
* 30 \\
* 55 \\
59 \\
* 25 \\
16 \\
* 50 \\
44 \\
* 40 \\
* 60 \\
13 \\
18 \\
* 50\end{array}$ & $\begin{array}{l}\mathbf{F} \\
\mathbf{M} \\
\mathbf{F} \\
\mathbf{M} \\
\mathbf{M} \\
\mathbf{F} \\
\mathrm{F} \\
\mathbf{F} \\
\mathbf{M} \\
\mathbf{M} \\
\mathbf{M} \\
\mathbf{M} \\
\mathbf{M} \\
\mathbf{M} \\
\mathbf{M} \\
\mathrm{F} \\
\mathbf{M} \\
\mathbf{F} \\
\mathbf{M}\end{array}$ & $\begin{array}{l}17 \\
10 \\
16 \\
20 \ddagger \\
14 \\
20 \\
11 \\
20 \ddagger \\
10 \\
20 \\
17 \\
10 \\
10 \\
10 \\
12 \\
6 \\
7 \\
11 \\
12\end{array}$ & $\begin{array}{r}640 \\
156 \\
600 \\
2,160 \\
360 \\
232 \\
720 \\
960 \\
1,480 \\
1,100 \\
570 \\
1,880 \\
1,520 \\
1,200 \\
1,440 \\
720 \\
400 \\
-\end{array}$ & $\begin{array}{l}\text { AA } \\
\text { AA } \\
\text { AS } \\
\text { AS } \\
\text { AA } \\
\text { AA } \\
\text { AA } \\
\text { AA } \\
\text { AA } \\
\text { AA } \\
\text { AA } \\
\text { AA } \\
\text { AA } \\
\\
\\
\text { AA }\end{array}$ & $\begin{array}{l}3 \\
2 \\
2 \\
2 \\
1 \\
3 \\
1 \\
3 \\
2 \\
1 \\
2 \\
1 \\
2 \\
2 \\
1 \\
1 \\
1 \\
2 \\
1\end{array}$ & $\begin{array}{l}0 \\
0 \\
3 \\
2 \\
0 \\
2 \\
0 \\
1 \\
1 \\
1 \\
0 \\
1 \\
0 \\
0 \\
0 \\
0 \\
0 \\
1 \\
0\end{array}$ & $\begin{array}{l}0 \\
0 \\
0 \\
0 \\
0 \\
1 \\
0 \\
0 \\
1 \\
0 \\
0 \\
0 \\
0 \\
0 \\
0 \\
0 \\
2 \\
0 \\
0\end{array}$ & $\begin{array}{c}5 \\
5 \\
4 \\
7 \cdot 5 \\
5 \\
10 \\
4 \\
6 \\
5 \\
2 \\
4 \\
0 \\
5 \\
6 \\
1 \\
0 \\
8 \\
7 \\
8\end{array}$ & $\begin{array}{l}\text { Hookworm. Cardiac failure. Strongyloides } \\
\text { Hookworm. Tuberculosis } \\
\text { Mitral incompetence. Cardiac failure } \\
\text { Hookworm. Pyelonephritis } \\
\text { Abortion. Hookworm } \\
\text { Schistosomiasis } \\
\text { Haematemesis. Leg ulcer } \\
\text { Pyelonephritis } \\
\text { Hookworm. Malnutrition } \\
\text { Strongyloides } \\
\text { Polyarthritis } \\
\text { Endomyocardial fibrosis } \\
\text { Nephrotic syndrome } \\
\text { Chronic lung disease }\end{array}$ \\
\hline
\end{tabular}

*Approximate.

+See text for measurement.

$\ddagger$ Right iliac fossa.
H.S.L. = Hepatical sinusoidal lymphocytosis.

TABLE II-Effect of Cycloguanil Pamoate (C.P.) on Spleen Size in 12 Patients

\begin{tabular}{|c|c|c|c|c|c|c|c|c|c|}
\hline \multirow[b]{2}{*}{$\begin{array}{l}\text { Case } \\
\text { No. }\end{array}$} & \multirow[b]{2}{*}{$\begin{array}{l}\text { Spleen } \\
\text { before } \\
\text { C.P. } \\
\text { (cm) }\end{array}$} & \multirow[b]{2}{*}{$\begin{array}{l}\text { Spleen } \\
\text { after } \\
\text { C.P. } \\
(\mathrm{cm})\end{array}$} & \multirow[b]{2}{*}{ Reduction } & \multicolumn{6}{|c|}{ Cycloguanil Pamoate } \\
\hline & & & & $\underset{\text { Injections }}{\text { No. of }}$ & $\begin{array}{l}\text { Total } \\
\text { Dose } \\
\text { (mg) }\end{array}$ & $\begin{array}{c}\text { Days } \\
\text { between } \\
\text { Injections }\end{array}$ & $\begin{array}{c}\text { Days } \\
\text { between } \\
\text { First Inj. } \\
\text { and } \\
\text { Final Exam. }\end{array}$ & $\begin{array}{c}\text { Days } \\
\text { between } \\
\text { Last Inj. } \\
\text { and } \\
\text { Final Exam. }\end{array}$ & Comment \\
\hline 1 & 17 & $0 \rightarrow 8$ & 53 & 5 & 1,470 & $107,214,96$, & 529 & 27 & Initial response with relapse (See also text) \\
\hline $\begin{array}{r}2 \\
5 \\
6 \\
7 \\
8 \\
9 \\
10 \\
11 \\
14 \\
16 \\
19\end{array}$ & $\begin{array}{l}10 \\
14 \\
20 \\
11 \\
20^{*} \\
10 \\
20 \\
17 \\
10 \\
6 \\
12\end{array}$ & $\begin{array}{r}2 \\
14 \\
13 \\
50 \\
11 \\
10 \\
20 \\
8 \\
0 \\
5 \cdot 5 \\
1\end{array}$ & $\begin{array}{r}80 \\
35 \\
55 \\
45 \\
\\
53 \\
100 \\
75\end{array}$ & $\begin{array}{l}3 \\
1 \\
1 \\
3 \\
2 \\
1 \\
2 \\
2 \\
1 \\
1 \\
1\end{array}$ & $\begin{array}{r}1,050 \\
840 \\
840 \\
1,050 \\
700 \\
350 \\
700 \\
700 \\
840 \\
210 \\
350\end{array}$ & $\begin{array}{c}155,279 \\
87,105 \\
70 \\
103 \\
132\end{array}$ & $\begin{array}{r}458 \\
22 \\
90 \\
283 \\
160 \\
37 \\
133 \\
181 \\
344 \\
30 \\
89\end{array}$ & $\begin{array}{r}24 \\
22 \\
90 \\
191 \\
90 \\
37 \\
30 \\
49 \\
344 \\
30 \\
89\end{array}$ & $\begin{array}{l}\text { Good response } \\
\text { Follow-up too short } \\
\text { Response } \\
\text { Good response } \\
\text { Good response } \\
\text { Follow-up too short } \\
\text { No response } \\
\text { Good response } \\
\text { Good response } \\
\text { Follow-up too short } \\
\text { Good response }\end{array}$ \\
\hline
\end{tabular}

*Right iliac fossa.

TABLE III-Effect of Cycloguanil Pamoate and/or Proguanil on Spleen Size in Four Patients

\begin{tabular}{|c|c|c|c|c|c|c|c|c|c|c|c|c|}
\hline & & & & \multicolumn{5}{|c|}{ Cycloguanil Pamoate } & \multicolumn{3}{|c|}{ Proguanil } & \multirow[b]{2}{*}{ Comment } \\
\hline $\begin{array}{l}\text { Case } \\
\text { No. }\end{array}$ & $\begin{array}{c}\text { Spleen } \\
\text { before } \\
(\mathrm{cm})\end{array}$ & $\begin{array}{l}\text { Spleen } \\
\text { after } \\
(\mathrm{cm})\end{array}$ & $\begin{array}{c}\% \\
\text { Reduc- } \\
\text { tion }\end{array}$ & $\begin{array}{c}\text { No. of } \\
\text { Injections }\end{array}$ & $\begin{array}{l}\text { Total } \\
\text { Dose } \\
(\mathbf{m g})\end{array}$ & $\begin{array}{c}\text { Days } \\
\text { between } \\
\text { Injections }\end{array}$ & $\begin{array}{l}\text { Days } \\
\text { between } \\
\text { First Inj. } \\
\text { and Final } \\
\text { Exam. }\end{array}$ & $\begin{array}{l}\text { Days } \\
\text { between } \\
\text { Last Inj. } \\
\text { and Final } \\
\text { Exam. }\end{array}$ & $\begin{array}{c}\text { No. of } \\
\text { Days } \\
\text { Given }\end{array}$ & $\begin{array}{l}\text { Daily } \\
\text { Dose } \\
\text { (mg) }\end{array}$ & $\begin{array}{l}\text { Total } \\
\text { Dose } \\
\text { (mg) }\end{array}$ & \\
\hline $\begin{array}{r}3 \\
4 \\
12 \\
13\end{array}$ & $\begin{array}{l}16 \\
20 \\
10 \\
10\end{array}$ & $\begin{array}{r}8 \\
14 \\
10 \\
6\end{array}$ & $\begin{array}{l}50 \\
30 \\
40\end{array}$ & $\begin{array}{l}3 \\
4 \\
1\end{array}$ & $\begin{array}{r}840 \\
1,190 \\
210\end{array}$ & $\begin{array}{l}119,183 \\
92,91,107\end{array}$ & $\begin{array}{l}384 \\
533\end{array}$ & $\begin{array}{l}146 \\
243\end{array}$ & $\begin{array}{r}56 \\
101 \\
19 \\
34\end{array}$ & $\begin{array}{l}300 \\
200 \\
100 \\
400\end{array}$ & $\begin{array}{l}16,800 \\
20,210 \\
1,900 \\
13,600\end{array}$ & $\begin{array}{l}\text { Good response } \\
\text { Response } \\
\text { Follow-up too short } \\
\text { Response }\end{array}$ \\
\hline
\end{tabular}


IgM levels in 17 cases of tropical splenomegaly syndrome with hepatic sinusoidal lymphocytosis before treatment ranged from 156 to $2,160 \mathrm{mg} / 100 \mathrm{ml}$, with a mean of $949 \mathrm{mg} / 100 \mathrm{ml}$. This was significantly higher than the mean of $384 \mathrm{mg} / 100 \mathrm{ml}$ in the 23 cases with splenomegaly of diverse cause, or the mean of $198 \mathrm{mg} / 100 \mathrm{ml}$ in the seven patients without splenomegaly. The range and mean of these results may be compared with the normal adult Nigerian range and mean (50-400, mean 189 $\mathrm{mg} / 100 \mathrm{ml}$ ), and the range and mean from Nigerians with tropical splenomegaly syndrome who respond to antimalarial therapy $(860-3,000$, mean $1,799 . \mathrm{mg} / 100 \mathrm{ml})$ and Nigerians with tropical splenomegaly syndrome who do not respond to antimalarial therapy (20-325, mean $81 \mathrm{mg} / 100 \mathrm{ml}$ ) (Sagoe, 1970).

From Table $I$ it is apparent that most patients had other diseases in addition to tropical splenomegaly syndrome. While some of these may have contributed to the anaemia, there is no evidence that they were the cause of the splenomegaly. The presence of multiple morbidity is similar to our previous experience with Zambian patients. Cases 3 and 4 were found to be carriers of the sickle-cell trait. These were two of the oldest patients in the group and were the only ones to have appreciable adenopathy. Lymph node bicpsy in Case 4 showed some lymphocytic proliferation, but not of a degree to suggest lymphoma.

\section{EFFECT OF TREATMENT}

In the group of 12 cases treated with cycloguanil (Table II) three were under observation for only three to five weeks; none of these showed any change in spleen size. Previous experience indicated that treatment often has to be continued for at least three months before any appreciable effect is noticed. One patient (Case 10) who was observed for 113 days showed no significant reduction in spleen size, and is classified as a non-responder. One other patient who showed no response after 192 days had considerable diminution in splenic size when seen after 283 days. There were therefore eight patients who showed a significant reduction in spleen size over periods ranging from 64 to 529 days, though in one patient this was temporary. This patient (Case 1) had a severe haemolytic anaemia and gross splenomegaly when first seen. After the administration of cycloguanil the spleen shrank and was impalpable after 82 days and the anaemia improved. Six months later, however, she was readmitted with increasing anaemia and jaundice. The spleen now measured $14 \mathrm{~cm}$, the cervical and axillary nodes were enlarged, and the haemolysis had returned-haemoglobin 7 $\mathrm{g} / 100 \mathrm{ml}$ and reticulocytes $25 \%$. Further injections of cycloguanil and the administration of proguanil had no effect. She was then given cyclophosphamide $250 \mathrm{mg}$ daily for 17 days. This resulted in a rise in haemoglobin, a decrease in reticulocytes, and a reduction in spleen size.

While this case fulfilled all the criteria for tropical splenomegaly syndrome, the presence of an overt haemolytic anaemia and the recrudescence of splenomegaly after an initial response are unusual. These features suggest that the patient may have developed a malignant lymphoreticular disease.

Two of the three cases treated with cycloguanil and proguanil showed pronounced reduction in spleen size; one case was not observed for sufficient time to assess the effect of treatment (Table III). One case treated with proguanil alone had an appreciable reduction in spleen size after 34 days. Five of those who responded to treatment had a second liver biopsv. In four of these there was a definite reduction in hepatic sinusoidal lymphocytosis after periods ranging from 90 to 408 davs. There was no change in the appearance in the fifth case but the time interval from the start of treatment was only 48 days.

\section{Discussion}

The initial clinical and laboratory findings in these cases are typical of tropical splenomegaly syndrome with hepatic sinusoidal lymphocytosis, though the finding of two cases with haemoglobin AS on electrophoresis is unusual. Hamilton et al. (1969) found $\mathrm{Hb} \mathrm{AA}$ exclusively in 143 patients with tropical splenomegaly syndrome in Uganda. The rate of $14 \%$ in the 14 patients tested in this series compares with rates varying from 13.5 to $19.7 \%$ in representatives from the same tribal groups and districts in Zambia (Barclay et al., 1970); the significance of this requires a much larger study.

The effects of cycloguanil in nine patients observed for periods of from 64 to 529 days were, in the main, successful in reducing spleen size, and only one case failed to show any improvement. Earlier experience with long-term proguanil, however, suggests that therapy and observation should be continued for at least a year before one can classify cases as totally unresponsive. The relapse in Case 1 also suggests that splenomegaly may be influenced by other factors, such as an overt haemolytic anaemia, or alternatively, as Sagoe (1970) has implied, that unresponsiveness may indicate a lymphomatous transformation. In her series of cases recently reported from Nigeria, Sagoe showed that response to prolonged proguanil therapy was only found in cases of tropical splenomegaly syndrome with high IgM levels and with normal phytohaemagglutinin (PHA)-induced lymphocyte transformation. Non-responders, by contrast, had lower IgM levels and their lymphocytes failed to transform with PHA; some of the latter had clear-cut evidence of lymphomatous transformation.

In a recent double-blind therapeutic trial reported from Uganda it was shown that patients with tropical splenomegaly syndrome and hepatic sinusoidal lymphocytosis all responded well to long-term therapy with an initial course of primaquine followed by chloroquine. The possibility that both proguanil and chloroquine are acting as cytotoxic rather than antimalarial agents is discussed by Sagoe (1970) and by Stuiver et al. (1971); the overall evidence suggests that the latter mode of action is most likely to account for their therapeutic effect. The clear-cut distinction between responders and non-responders (Sagoe, 1970) is only partly borne out by the findings in this series. Of the 10 patients who showed a response to treatment, seven had IgM levels over $500 \mathrm{mg} / 100 \mathrm{ml}$ and two fell within the normal range for rural Africans. Four out of the five patients who had a second liver biopsy (all responders) showed a decrease in hepatic sinusoidal lymphocytosis. In the Nigerian series selection for inclusion in the trial did not include hepatic sinusoidal lymphocytosis on liver biopsy, though this was present more often in responders than in non-responders.

The results reported here and from Nigeria and Uganda indicate that prolonged antimalarial therapy is the treatment of choice in tropical splenomegaly syndrome. Our findings suggest that cycloguanil might be of value where facilities for attending follow-up clinics are poor, or where there is difficulty in ensuring that pills are taken, both situations not uncommon in rural areas where tropical splenomegaly syndrome is seen. Further studies using a variety of measurements, such as IgM levels and PHA transformation, are necessary in various geographical areas to determine whether responsiveness can always be predicted, to elucidate the relation between cases of tropical splenomegaly syndrome with and without hepatic sinusoidal lymphocytosis, and to evaluate the frequency of true neoplastic lymphoid proliferation.

We are grateful to the following staff members of the Royal Postgraduate Medical School: Dr. W. R. Pitney and Dr. J. R. Hobbs (immunological studies) and Professor C. V. Harrison (two spleen biopsies). Valuable assistance was also rendered by Dr. C. C. Draper (Ross Institute), Dr. J. Fine (Kitwe Central Hospital), Dr. G. P. T. Barclay (Rokana Corporation Abnormal 
Haemoglobin Research Unit, Kitwe, Zambia), and the following staff members of the Ndola Central Hospital: Drs. J. Nag and V. Poonasamy; Messrs. E. Chimolula, J. Wijnands, and J. Mpofu; and Sisters P. Webber, T. Jones, P. Jeffreys, and K. Hannon. Senior Chief Mushili of the Lamba made many follow-up observations possible.

The Permanent Secretary for Health, Zambia, has given M.N.L. and E.C.O'R. permission to publish. Without financial assistance from the Beit Trust and Zambia Copper Mining Companies this investigation would not have been possible. Professor M. S. R. Hutt is supported by the Wellcome Trust.

\section{References}

British Medical fournal, 1967, 4, 614.

British Medical fournal, 1969, 4, 4.
Barclay, G. P. T., Jones, H. I., and Splaine, M. (1970). Transactions of the Royal Society of Tropical Medicine and Hygiene, 64, 78.

Hamilton, P. J. S., et al. (1969). Lancet, 2, 209.

Lowenthal, M. N., Hamilton, J. S., Hutt, M. S. R., and Wilks, N. .E (1966). Central African fournal of Medicine, 12, 99.

Lowenthal, M. N., and Hutt, M. S. R. (1968). East African Medical fournal, $45,100$.

Mancini, G., Carbonara, A. D., and Heremans, J. F. (1965). Immunochemistry, 2, 235.

Marsden, P. D., et al. (1967). Bulletin of the World Health Organization, 36, 901 .

Marsden, P. D., and Hamilton, P. J. S. (1969). British Medical fournal, 1,

Pitney, W. R. (1968). Transactions of the Royal Society of Tropical Medicine and Hygiene, 82, 717.

Sagoe, A.-S. (1970). British Medical fournal, 3, 378.

Stuiver, P. C., Ziegler, J. L., Wood, J. B., Morrow, R. H., and Hutt, M. S. R. (1971). British Medical fournal, 1, 426.

Watson-Williams, E. J., and Allan, N. C. (1968). British Medical fournal, 4, 793 .

\title{
Myocardial Infarction and Deep-vein Thrombosis
}

\author{
A. N. NICOlaides, V. V. KAKKAR, J. T. G. RENNEY, P. H. KIDNER, D. C. S. HUTCHISON \\ M. B. CLARKE
}

British Medical fournal, 1971, 1, 432-434

\section{Summary}

In a study of 52 patients admitted into the coronary intensive care unit the incidence of deep-vein thrombosis was measured with the ${ }^{125}$ I-fibrinogen test. Of these patients 31 were eventually confirmed to be suffering from acute myocardial infarction. This preliminary study showed that in patients with a confirmed infarct who were not treated with anticoagulants the incidence of deep-vein thrombosis was $38 \%$ and in those treated it was $5.5 \%$. In patients who were "severely ill" from whatever the cause there was a high incidence of deep-vein thrombosis $(68 \%)$.

\section{Introduction}

The true incidence of deep-vein thrombosis cannot be estimated clinically because signs are unreliable in diagnosing the condition (Flanc et al., 1968; Negus et al., 1968). The ${ }^{125} \mathrm{I}-$ fibrinogen test, however, is an accurate method of detecting thrombosis at the earliest stage (Atkins and Hawkins, 1965; Flanc et al., 1968; Negus et al., 1968). By using a ratemeter (Kakkar et al., 1970b) the technique is rapid and simple and can be used as a routine-screening procedure in a large number of patients. This technique was adopted in the present study.

In the recent M.R.C. report (1969) post-mortem studies revealed pulmonary embolism in $8.3 \%$ of patients with acute myocardial infarction who died. In a study of 240 consecutive post-mortem reports of patients with acute myocardial infarction at King's College Hospital it was found that

King's College Hospital Medical School, London S.E.5

A. N. NICOLAIDES, F.R.C.s., Pfizer Research Fellow, Department of Surgery

V. V. KAKKAR, F.R.C.s., Lecturer in Surgery

J. T. G. RENNEY, F.R.C.s., Pfizer Research Fellow, Department of Surgery

P. H. KIDNER, M.R.C.P., Research Fellow in Pulmonary Physiology (Present appointment: Senior Registrar in Cardiology) D. C. S. HUTCHISON, M.R.C.P.GLASG., Lecturer, Pulmonary Research

M. B. CLARKE, B.sC., Senior Physicist
$19(7.9 \%)$ had macroscopic pulmonary emboli causing or contributing to their death (Nicolaides, 1970). Similar results have been obtained by others (Browder et al., 1959; Hilden et al., 1961; Kucera, 1966). The present study was prompted by the above findings, which suggested a high incidence of deep-vein thrombosis in association with myocardial infarction. There is no doubt that effective attempts to treat deep-vein thrombosis and prevent pulmonary embolism are more successful when carried out at an early stage (Kakkar et al., 1969).

\section{Patients and Methods}

Fifty-two patients admitted to the coronary intensive care unit were studied. All had been admitted as emergencies with acute chest pain and were well previous to this. Patients aged under 40 and those who had a history or clinical signs of deep-vein thrombosis were excluded. The diagnosis of myocardial infarction was subsequently confirmed in 31 patients according to electrocardiographic and enzymatic (serum aspartate aminotransferase and lactate dehydrogenase) evidence. Eighteen of the patients with a confirmed infarct were treated with anticoagulants. This was part of the routine management practised by some of the physicians under whose care the patients were admitted. In these a continuous intravenous infusion of heparin (10,000 units six-hourly for 36 hours) and oral anticoagulants were started immediately on admission if the infarct was obvious or as soon as it was confirmed, usually within 24 to 48 hours. Subsequently the dose of oral anticoagulants was regulated to maintain the prothrombin time between one and a half and two times the control value. The remaining 13 patients with confirmed infarcts were not treated with anticoagulants (Table I). Apart from anticoagulation both groups received identical treatment.

\section{DIAGNOSIS OF DEEP-VEIN THROMBOSIS}

All the patients were screened by the ${ }^{125}$ I-fibrinogen test, using the Pitman 235 isotope localization monitor (Kakkar et al., 1970b). The principle of this test is that ${ }^{125}$ I-fibrinogen injected into the circulation is incorporated into a forming thrombus, and this is detected by the increased radioactivity at that site. 